\title{
Current approaches on non-invasive prenatal diagnosis: Prenatal genomics, transcriptomics, personalized fetal diagnosis
}

\author{
Non-invasiv prenatal tanıda güncel yaklaşımlar: Prenatal \\ genomik, transkriptomik, bireysel fetal tanı
}

\author{
Tuba Günell, Mohammad Kazem Hosseini ${ }^{1}$, Ece Gümüşoğlu1 ${ }^{1}$, Görkem Zeybek², İsmail Dölekçap ${ }^{1}$, \\ İbrahim Kalelioğlu3 ${ }^{3}$ Ali Benian ${ }^{4}$, Hayri Ermiş3 ${ }^{3}$ Kılıç Aydınlı5 \\ 1 İstanbul University, Faculty of Science, Department of Molecular Biology and Genetics, İstanbul, Turkey \\ ${ }^{2}$ Çanakkale Provincial State Hospital, Clinic of General Obstetrics and Gynecology, Çanakkale, Turkey \\ 3İstanbul University İstanbul Faculty of Medicine, Department of Gynecology, İstanbul, Turkey \\ ${ }^{4}$ İstanbul University Cerrahpaşa Faculty of Medicine, Department of Gynecology, İstanbul, Turkey \\ ${ }_{5}$ Medicus Health Center, İstanbul, Turkey
}

\begin{abstract}
Recent developments in molecular genetics improved our knowledge on fetal genome and physiology. Novel scientific innovations in prenatal diagnosis have accelerated in the last decade changing our vision immensely. Data obtained from fetal genomic studies brought new insights to fetal medicine and by the advances in fetal DNA and RNA sequencing technology novel treatment strategies has evolved. Non-invasive prenatal diagnosis found ground in genetics and the results are widely studied in scientific arena. When Lo and colleges proved fetal genetic material can be extracted from maternal plasma and fetal DNA can be isolated from maternal serum, the gate to many exciting discoveries was open. Microarray technology and advances in sequencing helped fetal diagnosis as well as other areas of medicine. Today it is a very crucial prerequisite for physicians practicing prenatal diagnosis to have a profound knowledge in genetics. Prevailing practical use and application of fetal genomic tests in maternal and fetal medicine mandates obstetricians to update their knowledge in genetics. The purpose of this review is to assist physicians to understand and update their knowledge in fetal genetic testing from maternal blood, individualized prenatal counseling and advancements on the subject by sharing our experiences as İstanbul University Fetal Nucleic Acid Research Group. J Turk Soc Obstet Gynecol 2014;4:233-41
\end{abstract}

Key Words: Genomics, Non-invasive, prenatal diagnosis, fetal personalized medicine

Conflict of Interest: The authors reported no conflict of interest related to this article.

\section{Özet}

Son yıllarda moleküler genetik tanı yöntemlerindeki gelişmeler fetal genom ve fetal fizyoloji hakkındaki bilgilerimizin artmasına önemli katkılar sağlamıştır. Prenatal tanı yöntemlerinde dünyadaki gelişmeler çok hızlanmış ve önemli değişiklikler olmuştur. Fetal genetik ve genomik analizlerden elde edilen bilgiler bireysel fetal tıbba yeni yaklaşımlar getirmiştir. Fetal DNA ve RNA dizileme teknolojisinin gelişmesiyle, yeni tedavi olanakları tartışlmaya başlanmıştır. Noninvaziv doğum öncesi tanı genomik tıp alanında yerini almıs ve bu teknolojilerin ortaya çıkardığı sonuçlar bilimsel arenada paylaşılır duruma gelmiştir. Lo ve ark.'nın fetusa özgü gen dizilerinin maternal plazmadan çoğaltılabileceğini göstererek serbest fetal DNA'nın maternal plazma ve serum içinden izole edilebileceğini keşfetmeleri bu ilerlemenin ilk basamağıdır. Mikroarray teknolojisi ve dizileme çalısmalarındaki teknolojik hız tıbbın her alanını etkilediği gibi fetal tanıda da kendini göstermiştir. Doğum öncesi tanı çalışmaları ile ilgilenen her bilim insanının genomik bilgisinin bulunması çok önemli bir gereksinimdir. Fetal genomu analiz ederek tanı koymayı mümkün kılan testlerin gebelere uygulanmaya başlamasıyla özellikle jinekologların genetik ve genomik alanındaki ilerlemelerin pratiğe yansıması ile ilgili bilgi güncellemelerine ihtiyaçları vardır. Bu derlemenin amacı fetal nükleik asitlerin anne kanında keşiflerinden fetal genom dizilemesine, fetusa ait bireysel tanının gelişmesinden, kişiselleştirilmiş fetal tıp ile ilgili bilimsel yeniliklere kadar özellikle doğum öncesi tanı alanında çalışanlara genetik ve genomik alanındaki gelişmeler hakkında bilgi vermek ve İstanbul Üniversitesi Fetal Nükleik Asit Araştırma Grubu'nun deneyimlerini paylaşmaktır. J Turk Soc Obstet Gynecol 2014;4:233-41

Anahtar Kelimeler: Genomik, Non-invaziv prenatal tanı, bireyselleştirilmiş fetal tıp

Çıkar Çatışması: Yazarlar bu makale ile ilgili olarak herhangi bir çıkar çatışması bildirmemişlerdir.

Address for Correspondence/Yazıșma Adresi: Tuba Günel, PhD,

İstanbul University, Faculty of Science, Department of Molecular Biology and Genetics, İstanbul, Turkey

Phone: +90 21245557 00/15473_E-mail: gunel@istanbul.edu.tr

Received /Geliş Tarihi : 17.12.2013

Accepted/Kabul Tarihi : 26.07.2014 


\section{Free Fetal Nucleic Acids in Maternal Blood and Serum}

Non-invasive prenatal diagnosis (NIPD) has become the most groundbreaking topics in medicine in the last decades. It can be applied at any time throughout pregnancy without the risk of fetal loss being the most prominent advantage. Its diagnostic sensitivity in some genetic diseases is close to invasive procedures and close to $100 \%$ in some chromosomal anomalies. Furthermore, NIPD enables research on fetal physiology avoiding any harm to fetus making it promising for future studies. Technology that enables fetal genetic analysis without invasive procedures will not be limited to this topic for sure. Presumably and progressively, the method will catch on in other branches of medicine evolving routes of diagnosis and therapy as we know it. There is already a new era in oncology where free tumor DNA analysis helping to diagnose cancer prior to metastasis. Due to its unique state, obstetrics and gynecology frontiered this approach similar to ultrasound and laparoscopy. We believe that obstetricians should comprehend the new revelations as soon as possible. On this note we founded İstanbul University Fetal Nucleic Acid Research Group as a collaboration of İstanbul University Cerrahpaşa Medical Faculty Obstetrics and Gynecology Ward and İstanbul University Molecular Biology and Genetics Ward.

The first and most important step in NIPD is the isolation of fetal nucleic acids. Mandel and Mateis observed cell free fetal DNA and RNA in both healthy and diseased subjects' plasma in 1948(1). However this discovery was not given proper credit at the time since it was not fully comprehended. Isolation of cell free fetal DNA (cffDNA) in maternal serum in 1997 by Lo et al. was the corner stone for NIPD(2). Following the isolation of cffDNA numerous methods were developed to reveal genomic (DNA), transcriptomic (RNA) and proteomic functions via gene expression, gene quantification and genetic sequencing. Mounting these with advanced software technologies accelerated the progress in genetics in the last decade.

\section{Cell Free Fetal DNA (cffDNA)}

cffDNA has been shown to exist in maternal spinal fluid, urine and intra-abdominal peritoneal fluid(3). The ratio of cffDNA to free DNA in maternal serum serum is about $10 \%(3-19 \%)(2)$ cffDNA, due to its relationship with placental microparticles is not hydrolised by circulatory nucleases and stays stable(4). Ones the placental microparticals are cleared as in postpartum, is it quickly cleared from maternal circulation(5). The source of cffDNA in maternal circulation is placenta, fetal hematopoietic cells and fetal DNA itself(6). Physiological and clinical data reveal that most of free nucleic acids in circulation originate from placenta rather than fetal hematopoietic cells. cffDNA in maternal circulation can be detected as early as $28^{\text {th }}$ days after conception. Since fetoplacental circulation does not start at that time, cffDNA is more likely to be shed from trophoblasts rather than hematopoietic cells(7). Maternal cell free DNA has 162 to 169 base pairs. Placental cffDNA on the other hand, has 143 base pairs since it does not contain 20 base pair extension to attach to nucleus. Wataganara et al. (2004), published strong evidences supporting placental origin of cffDNA when they examined first trimester elective pregnancy terminations. The study examined 134 first trimester elective pregnancy terminations, where 71 patients were surgically extracted and 63 were medically (misoprostol) induced. CffDNA levels in maternal blood following surgical extractions were significantly higher due to fetomaternal bleeding and destruction of trophoblastic villi. On the other hand, in medically induced terminations, cffDNA was positive in maternal blood 11 days after initiation of termination. Wataganara believed that this delay was caused by the residual placental tissue in uterus(8).

Placental mass and circulatory fetal DNA levels do not correlate. Increased cffDNA in maternal blood is caused by placental hypoxia or trophoblastic destruction $(9,10)$. Even though most studies examined cffDNA in maternal blood, amniotic fluid is a good source of fetal DNA. Bianchi et al. showed that at 16-20 weeks of gestation, fetal DNA in amniotic fluid is 100 to 200 times the amount in maternal blood. It is hypothesized that cffDNA in amniotic fluid is more useful in illuminating fetal physiology. The introduction of cffDNA ignited many studies. The common terms used in molecular genetics were shown in Table 1.

\section{Cell Free Fetal RNA (cffRNA)}

Poon et al. (2000) isolated Y chromosome specific mRNA transcript from maternal blood in patients carrying male fetuses and showed that cell free fetal RNA (cffmRNA) can be used as independent fetal nucleic acid indicator in maternal blood. The half-life of placental mRNA in maternal blood is approximately 14 minutes and can be detected in maternal plasma at 4 weeks(11). In contrast to cffDNA, cffRNA levels do not increase as pregnancy proceeds(12). Furthermore, detection of cffmRNA in maternal plasma is not associated with paternal polymorphism(13). Extraction of gene transcripts specific to placenta such as $\beta$ HcG ( $\beta$ subunit of human chorionic gonadotropin) and hPL (human placental lactogen) advocates that fetal RNA in maternal plasma comes primarily from placenta(14). Fetal DNA and RNA circulating in maternal blood deflects the idea that placenta is an impermeable membrane.

\section{Collecting, Transporting and Storing Maternal Blood}

Following certain algorithms im collecting, transporting and storing maternal blood for NIPD avoids cffDNA destruction in samples. Since the ratio of cffDNA to maternal DNA is minute, proper transport and storage of samples is an important factor in reliability of the tests(15). Maternal cell lysis due to warm environment releases excess amounts of maternal DNA to serum, which in turn alters NIPD results. Quantitative measurements of fetal DNA in fetal aneuploidy scanning would be less reliable in such cases. Currently maternal blood is collected in EDTA containing sampling tubes. In order to avoid maternal cell lysis, it is advised to centrifuge blood within 6 hours of 
sampling(16,17). In 2013 Wong et al. compared efficiency of new blood collection tubes (BCT's) to standard EDTA tubes. The study revealed that the new BCT's contain chemicals which prevent maternal cell destruction and allow longer storage time. The study stored blood samples for two days and tested at from 4 to 37 Celsius degrees for one through 14 days. Results

Table 1. Several terms used in molecular genetics

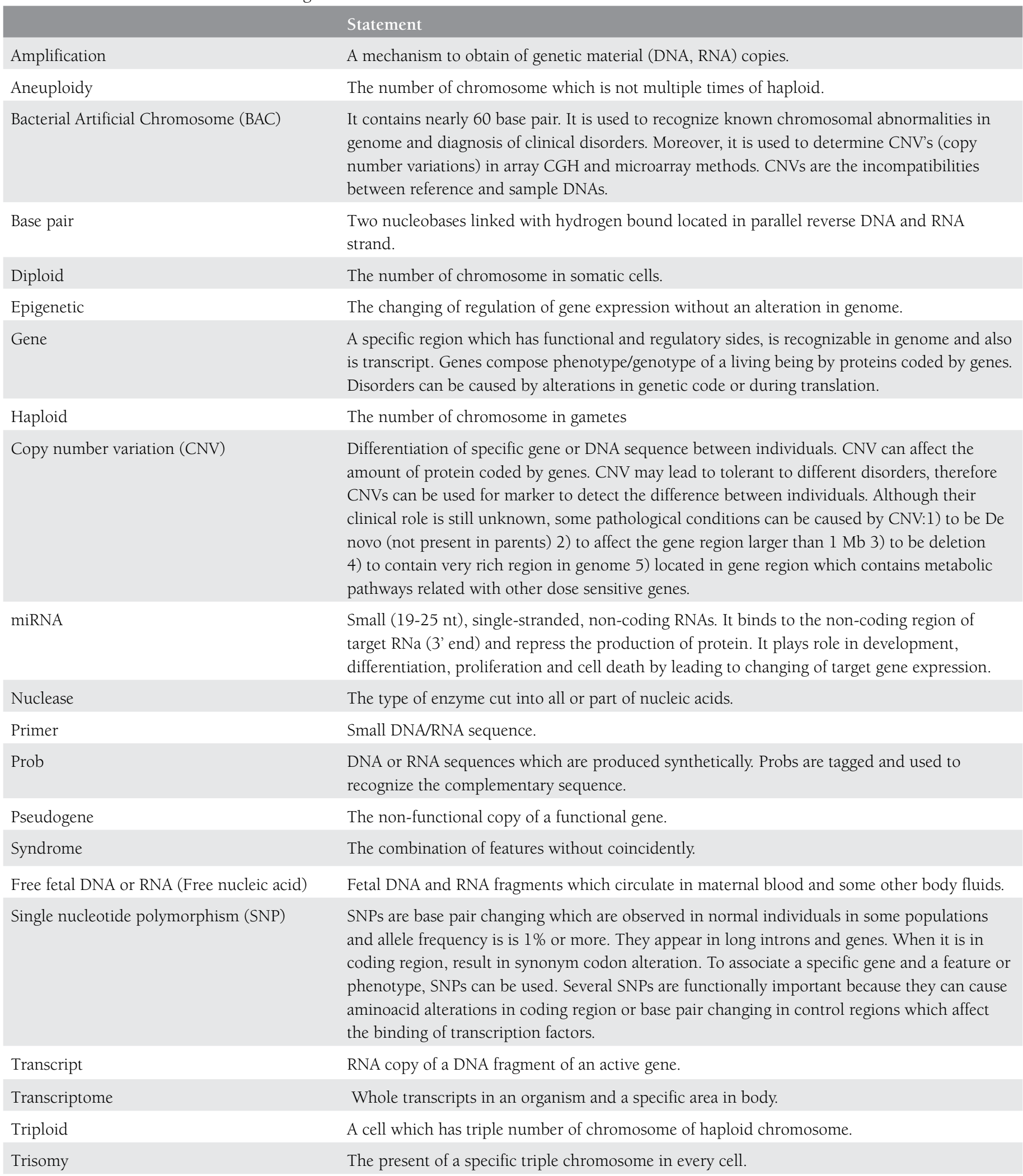


showed that maternal cell destruction started after 14 days which caused increased maternal DNA amounts. Currently BCT use is only approved for research purposes, however based on the results of this study, isolation of cffDNA from maternal blood can beneficiary using cell stabilizing chemicals(16-18).

\section{Analysis Methods and Advances in Non-invasive Molecular Diagnosis}

cffDNA and cffRNA technology is a rapidly improving area in NIPD. Indebted to advances in molecular analysis technology, cytogenetics has gained depth and detail. We summarized principles of mechanism and resolutions in Table 2 and Figure 1 respectively.

\section{Evaluation of Array Comparative Genomic Hybridization and Microarray Methods}

Array comparative genomic hybridization (aCGH) and microsequencing are innovative technologies with different clinical applications. Both methods give high resolution analysis (0.05-0.1 $\mathrm{Mb}$ ) of nucleic acids and commonly referred as microarray method in literature. Main difference lies in clinical application. Genetic material is identical in every cell with rare exceptions such as somatic mutations and placental mosaicism. Array CGH compares two different genomes for DNA repetition numbers. It is primarily used for diagnosing micro-deletion and micro-duplication syndromes by calculating number of repetitions on DNA segments. Microarray method usually applies to RNA. Gene expression profile varies according to the cellular phase and environment. Microarray is simply the tool to describe these conditions. In short, microarray reveals alterations in gene expression (transcriptomic microarray). Alterations in gene expression in certain conditions are monitored to acquire clues about the proteins coded by specific genes. Microarray method is used to monitor gene expression patterns in various physiological or pathological events.

\section{Fetal Transcriptomic Analysis}

Fetal transcripts in maternal blood are extremely scarce since most of the genetic material is of maternal origin. It has been hypothesized that ${ }^{(40)}$ amniotic supernatant contains enough free fetal RNA to reveal gene expression patterns on human growth. The study concluded that fetal gene expression modifies according to geststional age and sex. Amniotic transcriptomes from trisomy 21 and 18 subjects were compared healthy controls for the same gestational age and sex where both aneuploidies showed hundreds of statistically significant genetic alterations among which very little was chromosome mapped. Tree hundred eleven genes out of 414 were unalike in trisomy 21 subjects where only 5 of those were localized on chromosome 21 . Similarly, 251 genes out of 352 were miscorrelated in trisomy 18 subjects and only 7 of those were located on chromosome 18(41). These findings prove that pathologies in aneuploidic fetus does not solely result from the extra chromosome ordered gene amounts.

\section{Clinical Applications}

\section{Non-invasive Diagnosis of RH Disease}

Hemorrhagic disease of the newborn (erythroblastosis fetalis) is a disorder where paternal erythrocytes carry rhesus antigen and maternal cells do not. When the mother is encountered with $\mathrm{RH}$ positive antigens, the antibodies produced to these antigens can travel through placenta to aggregate RH positive fetal cells. Detecting fetal RH antigens from free fetal DNA in maternal blood is approved by International Blood Type Reference Laboratories since 2001 after successful preclinical trials(50). However, the large scale studies in France and Netherlands revealed some obstacles in noninvasive RHD tests. False negative results are usually caused by low fetal DNA counts due to either biological (very early pregnancy) or technical (low extraction rate) problems. In order to overcome these biases, recent studies advised the introduction of additional PCR

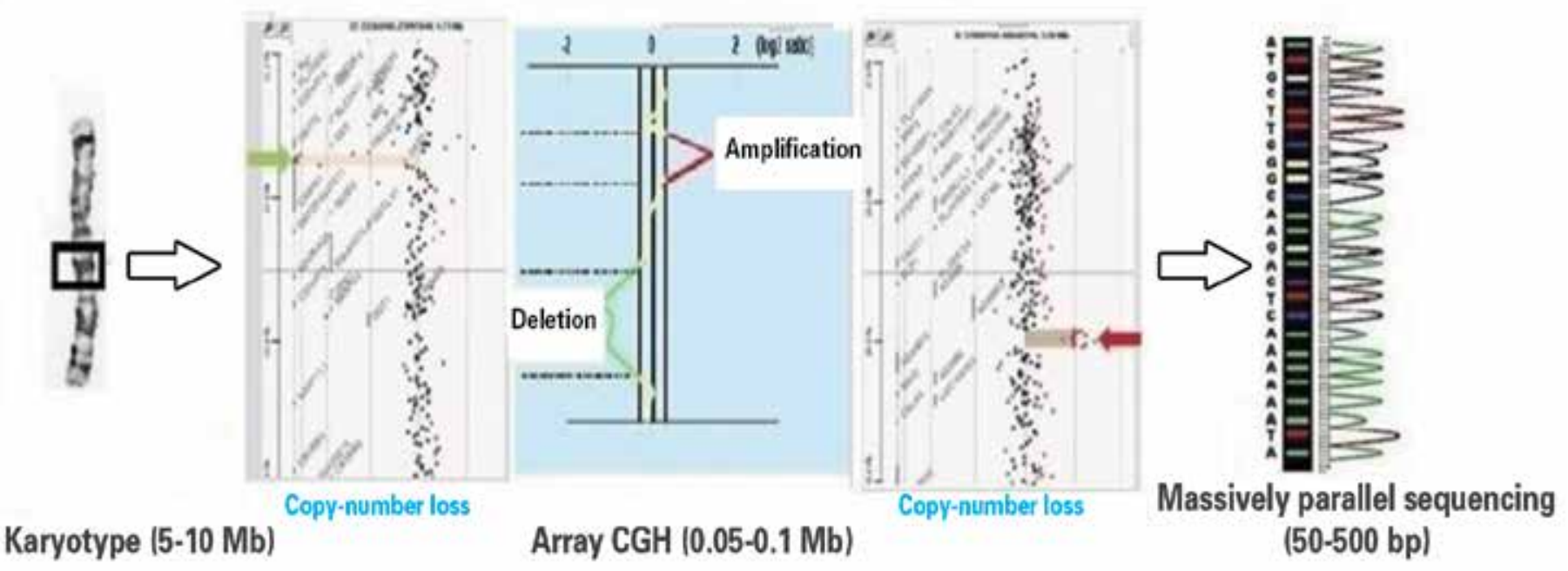

Figure 1. Comparing DNA region analysis by using conventional cytogenetic chromosome banding, array CGH and massively parallel sequencing methods 
methods; SRY region in y chromosome, differentially methylated placental DNA marker RASSF1A or paternal genetic markers as secondary internal controls. Usually false positive results occur in African originated RH negative subjects in the presence of two RHD variants; RHD pseudo-gene or RHD-CE-Ds hybrid sequences. Following the description of these variants, specific primers and probes were manufactured to detect and avoid false positive amplification(51,52). We studied $70 \mathrm{RH}$ incompatible patients and diagnosed 48 RHD positive, 19 RHD negative and 3 RHD variant fetuses. All non-invasive tests were confirmed postnatally $(50,51)$.

\section{Non-invasive Diagnosis of Sex Linked Diseases}

PCR multiplication of cffDNA in maternal blood is now an alternative to invasive procedures for fetal sex determination. It can be preferred in $\mathrm{X}$ linked diseases, ambiguous genitalia in ultrasound exam or in cases of congenital adrenal hyperplasia trait where early administration of steroids in order to prevent female fetus from masculinisation is crucial. The statistical power for non-invasive fetal sex determination was the subject of 57 studies and meta-analysis of 80 different data sets on 6541 singleton pregnancies, concluding $95.4 \%$ specifity and $98.1 \%$ sensitivity. The main parameters affecting non-invasive sex determination results were gestational age and DNA amplification method. Nevertheless, England endorsed NIPD of fetal sex in an attempt to decrease the frequency of invasive testing for sex linked diseases(53). As İstanbul University Fetal Nucleic Acid Research
Group, we determined 30 patients prenatally confirming the sex after birth.

\section{Non-invasive Diagnosis in Single Gene Disorders}

The sensitivity and specifity of NIPD in the first trimester is still limited because maternal and fetal DNA are aliened in serum(54). Enrichment of fetal DNA in maternal plasma can increase the precision and enable further analysis for diseases such as achondroplasia, hemoglobinopathies, congenital adrenal hyperplasia, cystic fibrosis, Huntington Disease and myotonic dystrophia(55).

One of the common single gene disorders constituting a public health issue in Turkey is thalassemia. There are 400 mutations in the thalassemia gene described up-to-date ${ }^{(56)}$. The diagnosis involves molecular methods, mainly by DNA extraction. In order to diagnose thalassemia in utero; amniotic fluid, chorion villus sampling or fetal blood were obtained invasively causing 0.5 to 1 percent fetal loss. Replacing invasive testing with NIPD methods is highly advocated and becoming widespread as new data keeps coming(57,58).

\section{NIPD of Fetal Aneuploidies}

Compared to other prenatal disorders, diagnosis of fetal aneuploidies requires more delicate technical methods since there is not a single mutation or defect. The studies revealed that cffDNA in maternal plasma and serum increase in Trisomy 21

Table 2. Molecular tests used for fetal diagnosis and treatment

Test Molecular Statement

Real-time PCR (RT-PCR)

Real-time PCR gives quantitative result by measuring nucleic acid amplification and the increasing of real-time fluoresce signal $(19,20)$.

Digital Polymerase Chain Reaction (Digital Digital PCR contains multiple PCR reactions and measure the number of target nucleic acid PCR, dPCR) based on dilution of nucleic acid, thus it is possible to gain single signal from single molecule. The positive amplification rate obtained from all PCR analysis is used for predict concentration of target fragment in non-diluated sample(21-29).

Microarray-Based Comparative Genomic Hybridization (Array CGH)

Microarray

Massively Parallel (Shot-gun) Sequencing, (MPSS)

Targeted massively parallel sequencing
"Array CGH" technology or molecular karyotyping have ability high resolution detection of micro-deletion and duplication which cannot detected by normal conventional cytogenetic (G-band karyotyping) techniques. While 5-10 Mb variations can be detected by present conventional cytogenetic, 0.05-0.1 Mb variations can recognized by aCGH technologies(30-33).

Microarray is a new and powerful technology to analyze gene expression changing in cell and tissue. DNA/RNA microarray is DNA/RNA ordered spots attached with glass, plastic or silicon chips. These attached DNA/RNA fragments (generally 20-100 nucleotides length) in surface are described prob(34-43). DNA/RNA amount is detected by fluorescence reaction.

After completion of human genome sequencing, every sequenced DNA fragment can be detected that which part of specific chromosome fragment(44-45). "Massively parallel (Shotgun) sequencing" is a method to detect and recognition the high amount of DNA fragments in plasma sample. With this method cloned long fragments can divided into small subclones and sequenced. This method is named as 'shotgun' because it sequences all informative chromosome regions and enumerate. 50-500 bp fragments can be read by this technique(46-48).

It is method to amplify a specific chromosomal area (e.g., chromosome $13,18,21$ ) selectively. After amplification, it can evaluate whether presenting chromosomal redundancy, according to the number of DNA fragment in euploid sample(49). 
and 13(59-61) but remain constant in Trisomy 18(62). Two studies concluded that there is no correlation between cffDNA levels in maternal plasma or serum with respect to aneuploidies(60-63). The common opinion that there is a strongly probable correlation between increased cffDNA and aneuploidies resulted in using the cffDNA levels in second trimester in combination with quadruple test. This approach increased detection rate of Down Syndrome in second trimester from 81\% to 86\%(64).

Epigenetic modifications are other proposed markers for prenatal diagnosis. Epigenetic modifications ie. DNA methylations, are alterations in gene expression or phenotype without modification in DNA sequence(65). Discovery of DMR's (Differentially Methylated Regions); which simply are dissimilar methylated maternal and fetal DNA fragments, enabled to differentiate maternal and paternal alleles in the fetus(66). Epigenetic-genetic chromosome quantification method uses holocarboxylase synthetase (HLCS) gene putative promoter. HLCS gene is located on chromosome 21 and assures diagnosis of Trisomy 21 in both male and female subjects(67). Maspin is the first universal fetal DNA marker in maternal plasma. It is a placenta specific epigenetic marker which is found in methylated state in maternal leucocytes whereas hypomethylated in placenta(68). Maspin, also known as SERPINB5 gene, proves that placental and maternal cells are differentially methylated. This discovery enhanced utilizing epigenetic markers for the diagnosis of Trisomy $18(68,69)$ and searching for novel fetal markers for Trisomy 21(70,71). 114 regions on chromosome 21 were studied, resulting in discovery of 22 DMR's(72). Latest researches used methylated DNA immune precipitation (MeDiP) and RtPCR for non-invasive prenatal diagnosis of trisomy 21(73). They identified fetal DMR's methylation rate from maternal blood, and comparing it with 26 euploid controls, they were able to diagnose Trisomy 21 successfully. There are two important advantages to MeDiP compared to other epigenetic methods; the use of DMRs containing cutting regions and sodium bisulphate (methylation sensitive enzyme resulting in DNA lysis) is eliminated(74).

Microfluidic chips are developed in order to compare Trisomy 21 cell line with healthy human cell line(29). GAPDH (Glyceraldehyde Phosphate Dehydrogenase) locus levels on chromosome 12 were compared with amyloid gene sequence on chromosome 21. Even though the samples constituted only $10 \%$ of total material (sample/number), digital PCR could differentiate between healthy and aneuploidic subjects reliably proving it to be more sensitive than RT-PCR and fluorescent QF-PCR(23). Digital PCR studies enables diagnosis of fetal aneuploidies using cffDNA from maternal blood. Same researchers could appropriately diagnose fetal trisomies from 24 amniotic fluid samples and 16 chorion villus samples using microfluidic digital PCR method(75).

Lo et al. detected fetal aneuploidies using cffDNA and cffmRNA digital PCR method(22). Two digital PCR methods were developed for the NIPD of fetal aneuploidies. The first one is based on PLAC4 Mrna SNP method. PLAC4 is gene on chromosome 21 coding a specific placental mRNA. The allele rate in maternal blood of this particular mRNA can detect Trisomy 21 with 90 to $96.5 \%$ sensitivity(76). The second regimen relies on dosage method where comparison of two different loci dosages on chromosome 21 and chromosome 1 is studied. This regimen allows the detection of fetal aneuploidies even when there is minute amounts of (25\%) trisomic DNA. Improvements in digital PCR technique had great impact on DNA sequencing technology. Analysis of cffDNA in maternal plasma by MPSS-next generation sequencing-has been reported in two different studies in 2008(45,77). Following these two reports, cffDNA in maternal plasma of Trisomy 13, 18 and 21 were sequenced with high sensitivity and specifity $(78,79)$.

cffDNA results in maternal plasma obtained by MPSS regimen are listed in terms of Z-scores. Z-score basically reflects the measured value's standard deviation in multiples from median measurements. In healthy pregnancies, z-score distribution is similar to Gaussian curve which is under 3 for euploid fetuses. Z-score above 3 indicates Trisomy 21 with $99.87 \%$ probability(48). Chiu et al. are the first to validate the clinical applications of MPSS sequencing for cffDNA in maternal plasma(79). Study group consisted of 314 subjects under high risk for Trisomy 21. 2-plex sequencing yielded results with 100\% sensitivity and 97.9\% specifity. 8-plex sequencing were carried out in 753 maternal plasma samples revealing $79.1 \%$ detection rate and $98.9 \%$ specifity for Trisomy 21. Ehrich et al. studied 499 maternal plasma samples with MPSS and reported 100\% sensitivity and $99.7 \%$ specifity $(78)$. Sehnert et al. studied 119 cffDNA samples from maternal plasma by MPSS and detected Trisomy 18 in addition to Trisomy 21(80) with 100\% accuracy (8/8 for Trisomy 18 and 13/13 for Trisomy 21. Chen et al. examined 392 maternal plasma samples by MPSS for non-invasive prenatal diagnosis of Trisomy 13 and 18(81). This study determined the correct GC ratio by using non-repeatmasked reference genomes and bioinformatics. The sensitivity and specifity for Trisomy 13 was 100\% and 98.9\% respectively (25 out of 25). Similarly, the sensitivity and specifity for Trisomy 18 was found $91.8 \%$ and $98 \%$ respectively (34 out of 37 ). Although these findings are very promising and exiting, in the previous study DNA amounts were very small size and DNA sequencing was not carried out in a non-CLIA certified laboratory. Palomaki et al. performed clinical validations is order to overcome these bias(82). These scientists diagnosed Trisomy 21 by using "next generation sequencing" in 212 pregnancies carrying Trisomy 21 fetuses matching to 1484 euploid controls. They had $0.2 \%$ false positive rate and 98.6\% detection rate. The same researchers used MPSS to identify Trisomy 13 and 18 and published 100\% and 91.7\% detection rate for Trisomy 18 and Trisomy 13 respectively(83) and false positive rate 0.28 and $0.97 \%$ respectively.

Currently cffDNA analysis by MPSS is still vague in terms of prenatal diagnosis. Whether NIPD by MPSS should be carried out prior to invasive procedures in high risk pregnancies or replace all screening tests requires further evaluation. Evidently decreases in MPSS costs would aid the process. International Society for Prenatal Diagnosis (ISPD) published a guideline for 
screening strategies for aneuploidies in 2011. According to this guideline, non-invasive prenatal screening and diagnosis by fetal nucleic acids in maternal circulation is not yet validated and therefore not to be recommended in clinical practice(84). In response to this opinion, Palomaki et al. prepared a report on MPSS sequencing in Trisomy 21 fetuses, concluding that advanced screening tests and confirmation of MPSS positive results by invasive testing should be carried out(85). In light of these extensive scientific reports, MPSS is now used in US and Europe as method for aneuploidy diagnosis.

MPSS sequencing studies reveal over 99\% sensitivity and specifity for the diagnosis of autosomal trisomies which are also feasible in multiple pregnancies. At this point, we should explore if the false positive results are caused by the method itself or the genetic material. Considering the rare occasions such as somatic mutations and placental mosaicism, and the knowledge we have so far obtained by invasive prenatal procedures, there are two possible reasons for false positivity. Infrequently, the necessity for additional invasive procedures arises. For instance, when confirmed by amniocentesis or fetal blood sampling, the 1-2\% mosaicism rate in CVS reduces to $0.15 \%$. cffDNA analyzed in MPSS is of placental origin. Therefore, there will be false positive results due to placental mosaicism (it seems impossible to evade false positive results due to placental mosaicism). In case of a pathologic finding in MPSS, it is advocated to keep placental mosaicism in mind and chose a method other than CVS.

The false negative outcomes in MPSS are mostly disciplinary. When MPSS analyses first started, EDTA containing sample collection tubes were used and there was not a consensus on required amounts of cffDNA or minimum base pair reads (sequence reads; $\mathrm{Meb}=\mathrm{M}$ ). The false negative cases in all series were from initiation stages. As the learning curve proceeded, BCT's (blood collection tubes) were introduced by Wong et al in 2013(18). These tubes enabled analysis of cffDNA without the influence of maternal maternal DNA. In consequence of this advancement, it is advised to have a minimum of $4 \%$ fetal DNA and 10 Meb (10 million) base pair reads for correct outcomes. Whether these criteria help diminish false negativity or not, is to be exposed in the near future.

\section{Conclusion}

RT-PCR, dPCR, Array CGH, microarray and MPSS methods are now available for research and NIPD. Merits to these methods, prenatal diagnosis of some fetal disorders is applied to clinical practice.

Some paternal inherited diseases such as achondroplasia, fetal sex, Rh factor and various single gene disorders can be diagnosed by NIPD. Array technology (microsequencing) detects quantitative and structural chromosome abnormalities causing genomic alterations with high accuracy.

Currently, it is possible to claim over 99\% sensitivity and specifity in diagnosis of fetal autosomal trisomies, Monosomy
$\mathrm{X}$, sex chromosome abnormalities, and microdeletion syndromes (DiGeorge, Cri-du-chat, 1p36, Angelman, Prader Willi) analyzing cffDNA from maternal blood via MPSS technology. It is advised to confirm positive test results affected fetus-with invasive procedures other than CVS. Whether NIPD by MPSS method should be done in high risk pregnancies prior to invasive procedures, or replace the current screening tests is to be decided in the near future. Clearly, a decrease in MPSS costs will affect the diagnosis algorithms. Scientifically speaking, NIPD by MPSS with its 99\% accuracy in autosomal trisomies, Monosomy X and some microdeletion syndromes will reduce invasive procedure rates by $90 \%$. NIPD will also endorse high detection rates in invasive tests and avoid "amniocentesis anxiety" in low risk patients (high risk in screening tests, advanced maternal age, minor marker presence in ultrasound).

\section{References}

1. Urbanova M, Plzak J, Strnad H, Betka J. Circulating nucleic acids as a new diagnostic tool. Cellular and Molecular Biology Letters 2010;15(2):242-59.

2. Lo YMD, Corbetta N, Chamberlian PF, Rai V, Sargent IL, Redman CW. Presence of fetal DNA in maternal plasma and serum. Lancet 1997;350:485-7.

3. Botezatu J, Serdyuk O, Potapova G, Shelepov V, Alechina R, Molyaka Y, et al. Genetic analysis of DNA excreted in urine: a new approach for detecting specific genomic DNA sequences from cells dying in an organism. Clin Chem 2000;46:1078-84.

4. Hui L, Bianchi DW. Cell-free fetal nucleic acids in amniotic fluid. Hum Reprod Update 2010;17:362-71.

5. Lo YM, Leung TN, Tein MS, Sargent IL, Zhang J, Lau TK, et al. Quantitative abnormalities of fetal DNA in maternal serum in preeclampsia. Clin Chem 1999;45:184-8.

6. Bianchi DW. Circulating fetal DNA: its origin and diagnostic potential-a review. Placenta 2004;25;93-101.

7. Guilbert J, Benachi A, Grebille AG, Ernault P, Zorn JR, Costa JM. Kinetics of SRY gene appearance in maternal serum: detection by real-time PCR in early pregnancy after assisted reproductive technique. Hum. Reprod 2003;18:1733-6.

8. Wataganara T, Chen AY, LeShane ES, Sullivan LM, Borgatta L, Bianchi DW, et al. Cell-free fetal DNA levels in maternal plasma after elective first-trimester termination of preganancy. Fertil Steril 2004;81:638-44.

9. Zhong XY, Holzgreve W, Hahn S. Circulatory fetal and maternal DNA in pregnancies at risk and those affected by preeclampsia. Ann N Y Acad Sci 2001;945:138-40.

10. Zeybek YG, Günel T, Benian A, Aydınlı K, Kaleli S. Clinical evaluations of cffDNA quantities in preeclamptic pregnancies. The Journal of Obstetrics and Gynaecology 2012;DOI: 10.1111/j.14470756.2012.02011.

11. Chiu RW, Lui WB, Cheung N, Kumta N, Farina A, Banzola I, et al. Time profile of appereance and disappereance of circulating placentadrived mRNA in maternal plasma. Clin Chem 2006;52:313-6.

12. Edlow AG, Bianchi DW. Tracking fetal development through molecular analysis of maternal biofluids. Biochimica et Biophysica Acta 2012;doi:10.1016/j.bbadis.2012.04005.

13. Maron JL, Bianchi DW. Prenatal diagnosis using cell free nucleic acids in maternal body fluids: a decate of progress. Am J Med Genet C Semin Med Genet 2007;145:5-17. 
14. Ng EK, Tsui NB, Lau TK, Leung TN, Chiu RW, Panesar NS, et al. mRNA of placental orijin is readily detectable in maternal plasma. Proc Natl Acad Sci USA 2003;100:4748-53.

15. Banerjee M, Misra D. Fetal nucleic acids in maternal circulation: A genetic resource for noninvasive prenatal diagnosis. ISRN Genetics Volume, 2013; Article ID 961293, 10 pages.

16. Fernando MR, Chen K, Norton S, Krzyzanowski G, Bourne D, Hunsley $\mathrm{B}$, et al. A new methodology to preserve the original proportion and integrity of cell-free fetal DNA in maternal plasma during sample processing and storage. Prenat Diagn 2010;30:418-24.

17. Barrett AN, Zimmermann BG, Wang D, Holloway A, Chitty LS. Implementing prenatal diagnosis based on cell-free fetal DNA: accurate identification of factors affecting fetal DNA yield. PLoS One 2011;6:25202

18. Wong D, Moturi S, Angkachatchai V, Mueller R, DeSantis G, van den Boom D, et al. Optimizing blood collection, transport and storage conditions for cell free DNA increases access to prenatal testing. Clinical Biochemistry 2013;46:1099-104.

19. Günel T. Gen anlatımının kantitatif analizi Real-Time PCR. Türkiye Klinikleri Tıp Bilimleri 2007;27(5):763-7.

20. Günel T, Ermiş H, Aydınlı K. Real-Time quantitative PCR for detection cell free fetal DNA, prenatal diagnosis - morphology scan and invasive methods, Richard Kwong Wai Choy and Tak Yeung Leung (Ed.), 2012; ISBN: 978-953-51-0614-2.

21. Chiu RW, Lau TK, Leung TN, Chow KC, Chui DH, Lo YM. Prenatal exclusion of beta thalassaemia major by examination of maternal plasma. Lancet 2002;360:998-1000.

22. Lo YM, Lun FM, Chan KC, Tsui NB, Chong KC, Lau TK, et al. Digital PCR for the molecular detection of fetal chromosomal aneuploidy. Proc Natl Acad Sci U S A 2007;104:3116-21.

23. Lun FM, Chiu RW, Chan KC, Leung TY, Lau TK, Lo YM. Microfluidics digital PCR reveals a higher than expected fraction of fetal DNA in maternal plasma. Clin Chem 2008;54:1664-72.

24. Lun FM, Tsui NB, Chan KC, Leung TY, Lau TK, Charoenkwan P, et al. Noninvasive prenatal diagnosis of monogenic diseases by digital size selection and relative mutation dosage on DNA in maternal plasma. Proc Natl Acad Sci U S A 2008;105:19920-5.

25. Tsui NB, Kadir RA, Chan KC, Chi C, Mellars G, Tuddenham EG, et al. Noninvasive prenatal diagnosis of hemophilia by microfluidics digital PCR analysis of maternal plasma DNA. Blood 2011;117:368491.

26. Ge Q, Bai Y, Liu Z, Liu Q, Yan L, Lu Z. Detection of fetal DNA in maternal plasma by microarray coupled with emulsions PCR. Clin Chim Acta 2006;369:82-8

27. Zimmermann B G, Grill S, Holzgreve W, Zhong XY, Jackson LG, Hahn S. Digital PCR: a powerful new tool for noninvasive prenatal diagnosis? Prenat Diagn 2008;28:1087-93.

28. Hahn S, Lapaire O, Tercanli S, Kolla V, Hosli I. Determination of fetal chromosome aberrations from fetal DNA in maternal blood: has the challenge finally been met? Expert Rev Mol Med 2011;13:16.

29. Fan HC, Quake SR. Detection of aneuploidy with digital polymerase chain reaction. Anal Chem 2007;79:7576-9.

30. Shinawi M, Cheung SW. The array CGH and its clinical applications. Drug Discov Today 2008;13:760-70.

31. Solinas-Toldo S, Lampel S, Stilgenbauer S, Nickolenko J, Benner A, Döhner $\mathrm{H}$, et al. Matrix-based comparative genomic hybridization: biochips to screen for genomic imbalances. Genes, Chromosomes and Cancer 1997;20:399-407.

32. Park SJ, Jung EH, Ryu RS, Kang HW, Ko JM, Kim HJ, et al. Clinical implementation of whole-genome array CGH as a first-tier test in 5080 pre and postnatal cases. Mol Cytogenet 2011;4:12.
33. Liu J, Bernier F, Julie L, Lowry RB, Chernos J. Application of microarraybased comparative genomic hybridization in prenatal and postnatal settings: three case reports. Genet Res Int 2011;2011:976398. doi: $10.4061 / 2011 / 976398$.

34. Elisavet AP, Philippos C. Non-invasive prenatal diagnosis of aneuploidies: new technologies and clinical applications. The Cyprus Institute of Neurology and Genetics 2012; PO Box 23462, 1683, Nicosia,

35. Qinya G, Yunfei B, Dihgdong Z. Microarray Detection of Fetal DNA Levels in Maternal Plasma 2007;40:1540-8.

36. Sri Venkateswara University, Current Knowledge on Microarray Technology, Tropical Journal of Pharmaceutical Research February 2012;11:153-64.

37. Choi S. DNA chips and microarray analysis, Handbook of fungal biotechnology. Marcel Dekker, Inc. (D. Arora, Ed) 2004.

38. Broer J. Advanced microarray technologies for clinical diagnostics. A catalogue record is available from the Eindhoven University of Technology library, 2011; ISBN: 978-94-6191-088-2.

39. Tsui NB, Chim SS, Chiu RW, Lau TK, Ng EK, Leung TN, et al. Systematic micro-array based identification of placental mRNA in maternal plasma: towards non-invasive prenatal gene expression profiling, J Med Genet 2004;41:461-7.

40. Lo YM, Tsui NB, Chiu RW, Lau TK, Leung TN, Heung MM, et al. Plasma placental RNA allelic ratio permits noninvasive prenatal chromosomal aneuploidy detection. Nat Med 2007;13:218-23.

41. Larrabee PB, Johnson KL, Lai C, Ordovas J, Cowan JM, Tantravahi U, et al. Global gene expression analysis of the living human fetus using cell-free messenger RNA in amniotic fluid. JAMA 2005;293:836-42.

42. Slonim DK, Koide K, Johnson KL, Tantravahi U, Cowan JM, Jarrah Z, et al. Functional genomic analysis of amniotic fluid cell-free mRNA suggests that oxidative stress is significant in Down syndrome fetuses. Proc Natl Acad Sci U S A 2009;106:9425-9.

43. Miura K, Miura S, Yamasaki K, Yoshida A, Yoshiura K, Nakayama D. Increased levels of cell-free placenta mRNA in a subgroup of placenta previa that needs hysterectomy. Prenat Diagn 2008;28:805-9.

44. Ng EK, Leung TN, Tsui NB, Lau TK, Panesar NS, Chiu RW, et al. The concentration of circulating corticotropin-releasing hormone mRNA in maternal plasma is increased in preeclampsia. Clinical Chemistry 2003;49:727-31.

45. Günel T, Zeybek YG, Akçakaya P, Kalelioğlu I, Benian A, Ermiş H, et al. Serum microRNA expression in pregnancies by preeclampsia. Genet Mol Res 2011;10:4034-40.

46. Fan HC, Blumenfeld YJ, Chitkara U, Hudgins L, Quake SR. Noninvasive diagnosis of fetal aneuploidy by shotgun sequencing DNA from maternal blood. Proc Natl Acad Sci U S A 2008;105:16266-71.

47. Chiu RW, Chan KC, Gao Y, Lau VY, Zheng W, Leung TY, et al. Noninvasive prenatal diagnosis of fetal chromosomal aneuploidy by massively parallel genomic sequencing of DNA in maternal plasma. Proc Natl Acad Sci U S A 2008;105:20458-63.

48. Lander ES. Initial impact of the sequencing of the human genome. Nature 2011:470:187-97.

49. Benn P, Cuckle H, Pergament E. Non-invasive prenatal testing for aneuploidy: current status and future prospects. Ultrasound Obstet Gynecol 2013;42:15-33.

50. Fan HC, Blumenfeld YJ, ChitkaraU, Hudgins L, Quake SR. Noninvasive diagnosis of fetal aneuploidy by shotgun sequencing DNA from maternal blood. Proc Natl Acad Sci U S A, 2008;105:16266-71.

51. Sparks AB, Wang ET, Struble CA, Barrett W, Stokowski R, McBride $C$, et al. Selective analysis of cell-free DNA in maternal blood for evaluation of fetal trisomy. Prenat Diagn 2012;32:3-9.

52. Günel T, Kalelioğlu İ, Ermiş H, Aydınlı K. Detection of fetal RhD gene from maternal blood. J Turk Ger Gynecol Assoc 2010;11:825 . 
53. Günel T, Kalelioglu İ, Gedikbaşı A, Ermiş H, Aydınlı K. Detection of fetal RHD pseudogene (RHD $\Psi$ ) and hybrid RHD-CE-Ds from RHDnegative pregnantwomen with a free DNA fetal kit. Genet Mol Res 2011;10:2653-7.

54. Günel T, Kalelioğlu İ, Sürmeli Y, Türken B, Ermiş H, Aydınlı K. Comparison of real-time polymerase chain reaction assay methods for detection of RHD gene in amniotic fluid. J Nat Sci Biol Med 2011;2:193-7.

55. Hill M, Finning K, Martin P, Hogg J, Meaney C, Norbury G, et al. Non-invasive prenatal determination of fetal sex: translating research into clinical practice. Clin Genet 2011;80:68-75.

56. Dündar YE. Anne kanında fetal nükleik asitlerle prenatal tanı uygulamas1, 2010;41.

57. Norbury G, Norbury CJ. Non-invasive prenatal diagnosis of single gene disorders: How close are we? Seminars in Fetal and Neonatal Medicine 2008;13:76-83.

58. HbVar: A database of Human Hemoglobin Variants and Thalassemias. Erişim: (http://globin.bx.psu.edu/cgi-bin/hbvar/counter) 2010. Erișim tarihi: 22.03.2010.

59. Cheung MC, Goldberg JD, Kan YW. Prenatal diagnosis of sickle cell anaemia and thalassaemia by analysis of fetal cells in maternal blood. Nature Genetics 1996;145:264-8.

60. Naro DE, Ghezzi F, Vitucci A, Tannoia N, Campanale D, D’Addario $\mathrm{V}$, et al. Prenatal diagnosis of $\beta$-thalassemia using fetal erithroblasts enriched from maternal blood by a novel gradient. Molecular Human Reproduction 2000;6:571-4.

61. Lee T, LeShane ES, Messerlain GM, Canick JA, Farina A, Heber WW, et al. Down syndrome and cell free fetal DNA in archived maternal serum. Am J Obstet Gynecol 2002;187:1217-21.

62. Spencer K, de Kok DB, Swinkels DW. Increased total cell free DNA in the serum of pregnant women carrying a fetus affected by trizomy 21. Prenat.Diagn 2003;23:580-3.

63. Lo YM, Lau TK, Zhang J, Leung TN, Chang AM, Hjelm NM, et al. Increased fetal DNA concentrations in the plasma of pregnant women carrying fetuses with trizomy 21. Clin Chem 1999;45:1747-51.

64. Wataganara T, LeShane ES, Farina A, Messerlian GM, Lee T, Canick JA, et al. Maternal serum cell free fetal DNA levels are increased in case of trizomy 13 but not trizomy 18. Hum Genet 2003;12:204-8.

65. Ohashi Y, Miharu N, Honda H, Samura O, Ohama K. Quantitation of fetal DNA in maternal serum in normal and aneuploid pregnancies. Hum Genet 2001;108:123-7.

66. Farina A, LeShane ES, Lambert-Messerlian GM, Canick JA, Lee T, Neveux LM, et al. Evaluation of cell free fetal DNA as a second trimester maternal serum marker of Down syndrome pregnancy. Clin Chem 2003;49:239-242.

67. Herman JG, Graff JR, Myohannen S, Nelkin BD, Baylin SB. Methylation specific PCR: a novel PCR assay for methylation status of CpG slands. Proc Natl Acad Sci USA 1996;93:9821-6.

68. Poon LL, Leung TN, Lau TK, Chow KC, Lo YM. Differential DNA methylation between fetus and mother as a strategy for detecting fetal DNA in maternal plasma. Clin Chem 2002;48:35-41.

69. Tong YK, Chiu RW, Akolekar R, Leung TY, Lau TK, Nicolaides KH, et al. Epigenetic-genetic chromosome dosage approach for fetal trisomy 21 detection using an autosomal genetic reference marker. PLoS One 2011;5:15244.

70. Chim SS, Tong YK, Chiu RW, Lau TK, Leung TN, Chan LY, et al. Detection of the placental epigenetic signature of the maspin gene in maternal plasma. Proc Natl Acad Sci U S A 2005;102:14753-8
71. Tong YK, Ding C, Chiu RW, Gerovassili A, Chim SS, Leung TY, et al. Noninvasive prenatal detection of fetal trisomy 18 by epigenetic allelic ratio analysis in maternal plasma: theoretical and empirical considerations. Clin Chem 2006;52:2194-202.

72. Old RW, Crea F, Puszyk W, Hulten MA. Candidate epigenetic biomarkers for non-invasive prenatal diagnosis of Down syndrome. Reprod Biomed Online 2007;15:227-35.

73. Oudejans CB. Noncoding RNA and DNA as biomarkers: toward an epigenetic fetal barcode for use in maternal plasma. Clin Chem 2008;54:456-7.

74. Rakyan VK, Down TA, Thorne NP, Flicek P, Kulesha E, Graf S, et al. An integrated resource for genome-wide identification and analysis of human tissue-specific differentially methylated regions (tDMRs). Genome Res 2008;18:1518-29.

75. Papageorgiou EA, Fiegler H, Rakyan V, Beck S, Hulten M, Lamnissou $\mathrm{K}$, et al. Sites of differential DNA methylation between placenta and peripheral blood: molecular markers for noninvasive prenatal diagnosis of aneuploidies. Am J Pathol 2009;174:1609-18.

76. Grunau C, Clark SJ, Rosenthal A. Bisulfite genomic sequencing: systematic investigation of critical experimental parameters. Nucleic Acids Res 2001;29:65-5.

77. Lo YM, Tsui NB, Chiu RW, Lau TK, Leung TN, Heung MM, et al. Plasma placental RNA allelic ratio permits noninvasive prenatal chromosomal aneuploidy detection. Nat Med 2007;13:218-23.

78. Fan HC, Blumenfeld YJ, Chitkara U, Hudgins L, Quake SR. Noninvasive diagnosis of fetal aneuploidy by shotgun sequencing DNA from maternal blood. Proc Natl Acad Sci U S A 2008;105:16266-71.

79. Ehrich M, Deciu C, Zwiefelhofer T, Tynan JA, Cagasan L, Tim R, et al. Noninvasive detection of fetal trisomy 21 by sequencing of DNA in maternal blood: a study in a clinical setting. Am J Obstet Gynecol 2011;204:201-11.

80. Chiu RW, Akolekar R, Zheng YW, Leung TY, Sun H, Chan KC, et al. Non-invasive prenatal assessment of trisomy 21 by multiplexed maternal plasma DNA sequencing: large scale validity study. BMJ 2011:342:7401.

81. Sehnert AJ, Rhees B, Comstock D, de Feo E, Heilek G, Burke J, et al. Optimal detection of fetal chromosomal abnormalities by massively parallel DNA sequencing of cell-free fetal DNA from maternal blood. Clin Chem 2011:57:1042-9.

82. Chen EZ, Chiu RW, Sun H, Akolekar R, Chan KC, Leung TY, et al. Noninvasive prenatal diagnosis of fetal trisomy 18 and trisomy 13 by maternal plasma DNA sequencing. PLoS One 2011;6:21791.

83. Palomaki GE, Kloza EM, Lambert-Messerlian GM, Haddow JE, Neveux LM, Ehrich M, et al. DNA sequencing of maternal plasma to detect Down syndrome: an international clinical validation study. Genet Med 2011;13:913-20.

84. Palomaki GE, Deciu C, Kloza EM, Lambert-Messerlian GM, Haddow JE, Neveux LM, et al. DNA sequencing of maternal plasma reliably identifies trisomy 18 and trisomy 13 as well as Down syndrome: an international collaborative study. Genet Med 2012;14:296-305.

85. Benn P, Borrell A, Crossley J, Cuckle H, Dugoff L, Gross S, et al. Aneuploidy screening: a position statement from a committee on behalf of the Board of the International Society for Prenatal Diagnosis. Prenat Diagn 2011;31:519-22. 